Dział: Medycyna Weterynaryjna i Nauki o Zwierzętach

Copyright @Wydawnictwo Uniwersytetu Przyrodniczego w Poznaniu

Magdalena HerudzińsKa, AleKSANDRA Kierbić, Julita KMIECIK, MareK GeHrKe, JĘDRZEJ M. JAŚKOWSKI

Veterinary Institute

Poznań University of Life Sciences

\title{
THE USAGE OF INSEMINATION CASING IN COLLECTING THE CYTOLOGICAL MATERIAL FROM THE COW'S UTERUS IN ORDER TO REDUCE THE METHOD'S INVASIVENESS
}

\author{
ZASTOSOWANIE OSŁONKI INSEMINACYJNEJ \\ PRZY POBIERANIU MATERIAŁU CYTOLOGICZNEGO Z MACICY KRÓW \\ W CELU ZMNIEJSZENIA INWAZYJNOŚCI METODY
}

\begin{abstract}
Summary
Background. Diseases of the uterus are one of the main factors limiting cow's fertility. The subclinical endometritis (endometritis subclinica) is a particular problem among different forms of post-partal metritis in this species because of its complicated diagnosing. In order to enhance the efficiency of uterus diseases diagnostics, different methods (such as cytology) are being applied. However, taking material for cytological examination is invasive and poses the risk of damage, especially while moving the brush inwards through the cervical canal. The purpose of our study was to test the invasiveness of the method in which commonly applied, sharp-edge cytological brushes are used compared with the invasiveness of the modified method in which the edge of the brush is round (covered with an insemination cover).

Material and methods. Material for the cytological examination was taken using both of the quoted methods from 60 cows which were proven to be free from endometritis. The cytological material was transferred to glass slides through rolling. The smears were fixed with Cytofix, stained with RapidHem and closely examined. The average erythrocyte and epithelial cell count in 50 fields of view at $100 \mathrm{X}$ magnification as well as the percentage of desquamated epithelial fragments (10 cells or more) were specified. The evaluation was conducted in three swab zones corresponding with the peak of the brush (zone I), its middle section (zone II) and its basal part (zone III).

Results and conclusions. A comparison of the results of the cytological examination using both methods (sharp-edge and insemination cover) indicated that the number of erythrocytes and the percentage of desquamated epithelial fragments in zone I is an accurate way of determining the invasiveness of the procedure. While using the insemination cover does not entirely eliminate trauma to the epithelium of the cervix, it does reduce the amount of desquamated epithelial frag-
\end{abstract}


Herudzińska, M., Kierbić, A., Kmiecik, J., Gehrke, M., Jaśkowski, J. M. (2016). The usage of insemination casing in collecting the cytological material from the cow's uterus in order to reduce the method's invasiveness. Nauka Przyr. Technol., 10, 4, \#55. DOI: http://dx.doi.org/10.17306/J.NPT.2016.4.55

ments. Therefore, it is less invasive. The low erythrocyte count in smears collected with the use of a brush covered with an insemination cover indicates that this type of safety measure ensures protection from a serious trauma.

Key words: endometrial cytology, cytobrush, insemination casing, Cassou insemination gun, SEND, metritis

\section{Introduction}

The diseases of the uterus are one of numerous causes of a decreased fertility of dairy cows (Dubuc et al., 2010; Podhalicz-Dziegielewska et al., 2011; Sheldon et al., 2009). Both clinical and subclinical endometritis are dominant among them (Amiridis et al., 2003; Gilbert et al., 2005; LeBlanc et al., 2002). The clinical metritis can be diagnosed basing on a gynaecological examination (Azawi, 2008; Sheldon et al., 2006), whereas the other type, i.e. the subclinical one (subclinical metritis, SEND) calls for additional specialist examinations (Sheldon et al., 2006). They are the endometrial biopsy and/or cytological examination of the smear taken from the body of the uterus or its horns (Ahmadi et al., 2005). There are advantages and disadvantages to each of the methods. The strong asset of the biopsy is the possibility of the histopathological evaluation of the deeper layers of the endometrium (Rodenbusch et al., 2007). It is though connected with a higher invasiveness of the method, since collecting the material disturbs the continuity of both shallow and deeper layers of the mucous membrane of the uterus. Due to this fact and others, the examination of the cytological material collected from the reproductive organs found a broader application in the SEND diagnostics (Ahmadi et al., 2006; Madoz et al., 2014). The heart of the method is the halfquantitative evaluation of the diversity of the cells present in the smear. It consists in defining the percentage of multinucleated cells (mainly neutrophils) in the field of view or their percentage to all the cells present in the smear (leucocytes and shedded epithelium cells) (Kasimanickam et al., 2004; Raab D., 2004; Santos et al., 2009). Cytological examination of the uterus can be carried out on cows 3-4 weeks or 45-50 days after the delivery (after the theoretical histological puerperium time has been exceeded), shortly before the optimum period of the first insemination procedures. Its purpose is to eliminate the subclinical form of endometritis which negatively influences the effectiveness of the insemination decreasing the fertilzed cows' rate (Kasimanickam et al., 2004; Plöntzke et al., 2010). The material for a cytological examination can be collected applying two techniques/methods: uterine lavage and brushing ("cytobrush"). The lavage technique consists in introducing of approx. $60 \mathrm{ml}$ of physiologic saline into the body of the uterus, and next sucking out possibly its highest content, centrifuging it to condense the cells rinsed out from the uterine cavity and evaluating the smear from the obtained suspension. The advantage of the method is a high representative character of a sample since cells originate from a large area of the mucous membrane and the uterus horns (Kasimanickam et al., 2005). The procedure of sucking out the saline from the uterus may be sometimes unsuccessful which is reported, among others, by Kasimanickam et al. (2005). The lavage technique/method, although more time and labour-consuming, is of a lower invasiveness. "Cytobrush" (McDougall et al., 2011; Melcher et al., 2014) is 
Herudzińska, M., Kierbić, A., Kmiecik, J., Gehrke, M., Jaśkowski, J. M. (2016). The usage of insemination casing in collecting the cytological material from the cow's uterus in order to reduce the method's invasiveness. Nauka Przyr. Technol., 10, 4, \#55. DOI: http://dx.doi.org/10.17306/J.NPT.2016.4.55

the most frequently recommended method in the SEND diagnostics. The technique applying the cytological brush is relatively simple (Oral et al., 2009; Prieto et al., 2012). It consists in introducing a stiff-catheter-covered brush into the reproductive tracts, moving it inward and collecting the material from the membrane of the body of the uterus and/or its horns. The catheter is supposed to facilitate the brush's introduction via the vaginal canal and reduce the risk of contaminating it by the material from the vagina and the cervix. Sometimes it is protected by a casing (soft polyethylene cover). While introducing the catheter or an original cytological kit via successive reproductive tracts sections there is a risk of micro traumas as a result of brushing of the catheter's edges and the cover against the membrane. Their presence is proved by the number of erythrocytes and batches of epithelial cells in the cytological smear.

The uterine cervix is the critical place where most of traumas take place. It needs to be observed though that the level of the invasiveness of the cytobrush does not result from the applied cover but from the phase of the estrus cycle the examined cow is in. The available original smear collecting kits/sets have a relatively sharp edge of the casing, similar to the metal catheters serving to introduce the brush. They can be successfully substituted by an insemination gun in which the brush is protected with an insemination casing with a round edge.

The purpose of the tests was an evaluation of the degree of the invasiveness of the "cytobrush" method using both the original kit/set and Cassou insemination gun depending on the cow's estrus cycle phase. Moreover, an influence of the cow's estrus cycle phase on the count of the polymorphonuclear (PMNs) cell fractions in the smears was evaluated.

\section{Material and methods}

60 clinically healthy dairy cows of the Polish breed HF were qualified for the tests. They were divided into two groups. Group 1 were 30 calved heifers between 55-70 days postpartum which were in the oestrus or close to the oestrus period.

Group 2 comprised of 30 cows above 70 days postpartum which showed no oetrus symptoms either in the exterior reproductive organs or in their behaviour. An additional criterion defining the cycle's phase was a gynaecological examination. It focused on the per vaginam evaluation of the dilation of the cervix and the volume of the vagina secretion and the degree of the myometrium tension was described via per rectum palpation, while the USG examination was used to identify the structures on the ovaries. The cytological material was collected from every cow on the same day applying the "cytobrush" method using both the original casing method and Cassou gun, as well as the insemination casing (Fig. 2). The procedure was always carried out by the same person. It needs to be stressed that the original set casing diameter and that of the cytological one were close to each other.

After the brush was released (Fig. 1) from the casing the cytological material was transferred to glass slides through rolling. The smears were fixed with Cytofix, stained with RapidHem and closely examined. 
Herudzińska, M., Kierbić, A., Kmiecik, J., Gehrke, M., Jaśkowski, J. M. (2016). The usage of insemination casing in collecting the cytological material from the cow's uterus in order to reduce the method's invasiveness. Nauka Przyr. Technol., 10, 4, \#55. DOI: http://dx.doi.org/10.17306/J.NPT.2016.4.55



Fig. 1. Cytology brush

Rys. 1. Szczoteczka cytologiczna

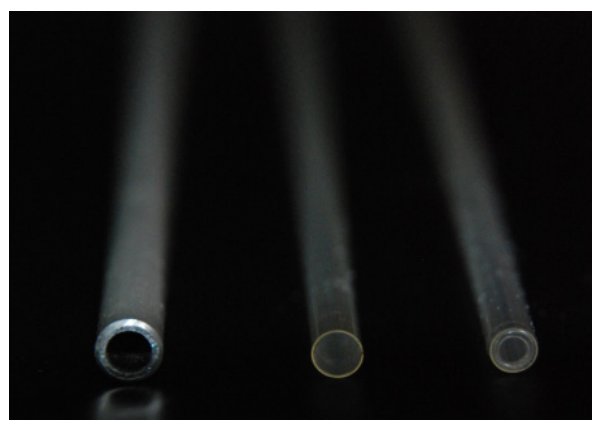

Fig. 2. Edges of casings (left to right: metal catheter, cytological brush casing, insemination casing)

Rys. 2. Krawędzie osłonek (od lewej: kateter metalowy, komercyjna osłonka cytologiczna, osłonka inseminacyjna)

After dessication the cells present in the smears were evaluated. The evaluation was conducted in three swab zones corresponding with the peak of the brush (zone I), its middle section (zone II) and its basal part (zone III) (Fig. 3). The average cell count in 50 fields of view was conducted in each of the zones. The count of erythrocytes, single epithelium cells (Fig. 4) and their batches (Fig. 5), leucocytes and PMNs (Fig. 6) was evaluated (Fig. 6). A group of more than 10 pieces was assumed as an epithelial cell batch. The statistical investigations comprised the analysis of variance and a division of means into groups applying t-Student's test. 
Herudzińska, M., Kierbić, A., Kmiecik, J., Gehrke, M., Jaśkowski, J. M. (2016). The usage of insemination casing in collecting the cytological material from the cow's uterus in order to reduce the method's invasiveness. Nauka Przyr. Technol., 10, 4, \#55. DOI: http://dx.doi.org/10.17306/J.NPT.2016.4.55

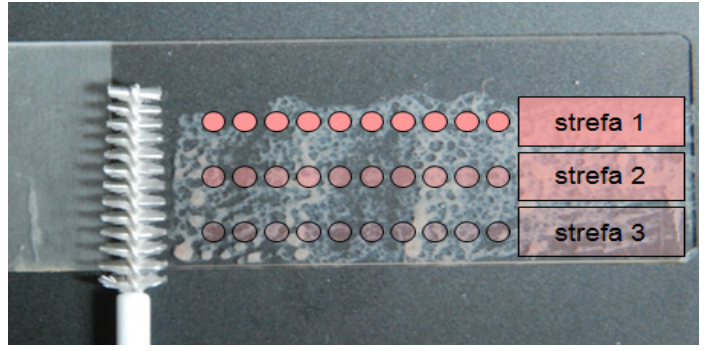

Fig. 3. Cytological smear zone-divisioned scheme Rys. 3. Schemat podziału rozmazu cytologicznego na strefy

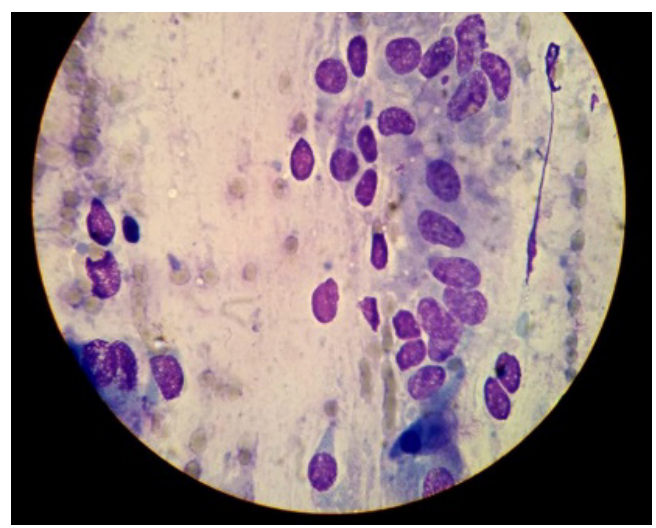

Fig. 4. Individual epithelial cells

Rys. 4. Pojedyncze komórki nabłonka

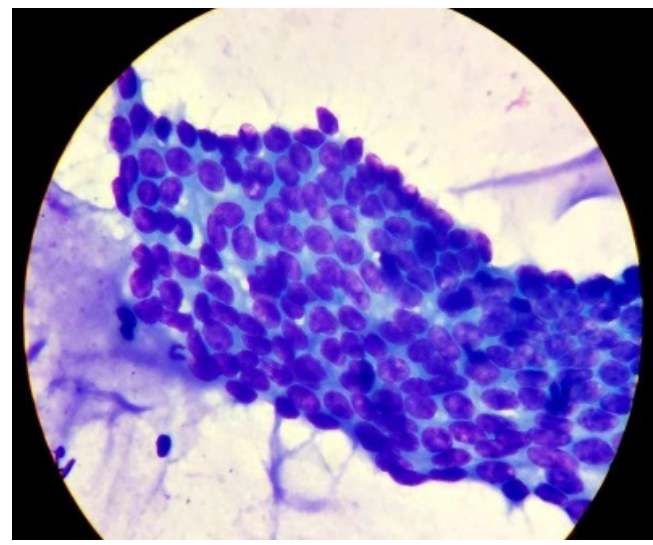

Fig. 5. Batch of epithelial cells

Rys. 5. „Pakiet” komórek nabłonka 
Herudzińska, M., Kierbić, A., Kmiecik, J., Gehrke, M., Jaśkowski, J. M. (2016). The usage of insemination casing in collecting the cytological material from the cow's uterus in order to reduce the method's invasiveness. Nauka Przyr. Technol., 10, 4, \#55. DOI: http://dx.doi.org/10.17306/J.NPT.2016.4.55



Fig. 6. Neutrophils

Rys. 6. Granulocyty obojętnochłonne

\section{Results and discussion}

The cytological images of the smears from the body of the uterus of cows from group 1 contained, on the average, a lower count of erythrocytes and epithelium cell batches compared to group 2 (respectively: $31.4 \pm 25.8$ and $23.8 \pm 11.1$, as well as 39.5 $\pm 29.4 \%$ and $38.9 \pm 8.5 \%$ ). An average count of erythrocytes and epithelial batches was the highest in the smear zone corresponding to the brush peak, while the lowest to its base. An average count of erythrocytes in the cytological material collected applying the insemination casing in both groups was lower compared to the smears obtained from the original sets application - Table 1 .

It is worth observing that the epithelial cell batches were found in each of the smears, yet with a changeable intensity which is depicted by the percentage (Table 1), calculated as the quotient of the number of the fields of view in which were the batches to the general number (50) of the fields in every zone.

It can be indicated, judging from the erythrocytes percentage in the smears, that the suggested method of material collecting for the cytological examination with Cassou gun does reduce approx. 5-fold the risk of damages to the endometrium down to the vascular zone and by about half the surface damages. The proved differences of the invasiveness of the examination measured by the count of erythrocytes and epithelium cells batches (Fig. 1 and 2) are in agreement with the data provided by Walter et al. (2012), who confirm the impact of the casing type on the invasiveness of the method. The differences in the count of erythrocytes and desquamated epithelial cells between the groups may result from the changes occurring in the uterine cervix wall and the degree of the dilation of the cervix canal in heat and outside the estrus period. While in heat the mucosa of the uterine cervix is softened, and its light is significantly broadened compared to the outside of the estrus period. Owing to this situation the easiness with which the cytological set is passed via the uterine cervix is varied. It is reflected in the count of erythrocytes and epithelial cell groups present in the cytological smears in cows 
Herudzińska, M., Kierbić, A., Kmiecik, J., Gehrke, M., Jaśkowski, J. M. (2016). The usage of insemination casing in collecting the cytological material from the cow's uterus in order to reduce the method's invasiveness. Nauka Przyr. Technol., 10, 4, \#55. DOI: http://dx.doi.org/10.17306/J.NPT.2016.4.55

Table 1. Results of the evaluation of smears from the material collected with usage of insemination and original casing. Erythrocytes, individual epithelial cells and percentage of batches of epithelial cells

Tabela 1. Wyniki badania cytologicznego rozmazów wykonanych z materiału pozyskanego z wykorzystaniem osłonki inseminacyjnej i komercyjnej. Liczba erytrocytów, pojedynczych komórek nabłonka i odsetek ,pakietów” komórek nabłonka

\begin{tabular}{|c|c|c|c|c|}
\hline \multirow{2}{*}{$\begin{array}{l}\text { Count of the examined cells } \\
\text { Liczba badanych komórek }\end{array}$} & \multicolumn{2}{|c|}{$\begin{array}{l}\text { Cows in heat and perioestral period } \\
\text { (group 1) } \\
\text { Krowy w rui i okresie okołorujowym } \\
\text { (grupa 1) }\end{array}$} & \multicolumn{2}{|c|}{$\begin{array}{l}\text { Cows except those in perioestral } \\
\text { period (group 2) } \\
\text { Krowy poza okresem okołorujowym } \\
\text { (grupa } 2 \text { ) }\end{array}$} \\
\hline & $\begin{array}{l}\text { insemination } \\
\text { casing } \\
\text { osłonka } \\
\text { inseminacyjna } \\
(\mathrm{n}=30)\end{array}$ & $\begin{array}{l}\text { original casing } \\
\text { osłonka } \\
\text { komercyjna } \\
(\mathrm{n}=30)\end{array}$ & $\begin{array}{l}\text { insemination } \\
\text { casing } \\
\text { osłonka } \\
\text { inseminacyjna } \\
(\mathrm{n}=30)\end{array}$ & $\begin{array}{l}\text { original casing } \\
\text { osłonka } \\
\text { komercyjna } \\
(\mathrm{n}=30)\end{array}$ \\
\hline \multicolumn{5}{|c|}{ Zone 1 - Strefa 1} \\
\hline $\begin{array}{l}\text { Erythrocytes } \\
\text { Erytrocyty }\end{array}$ & $12.6 \pm 8.8^{\mathrm{aA}}$ & $62.8 \pm 8.1^{\mathrm{cA}}$ & $20.2 \pm 10.2^{\mathrm{bA}}$ & $70.4 \pm 12.6^{\mathrm{dA}}$ \\
\hline $\begin{array}{l}\text { Individual epithelial cells } \\
\text { Pojedyncze komórki nabłonka }\end{array}$ & $12.0 \pm 4.6$ & $14.3 \pm 6.0$ & $15.9 \pm 6.7$ & $16.5 \pm 8.3$ \\
\hline $\begin{array}{l}\text { Batches of epithelial cells }(\%) \\
\text { „Pakiety” komórek nabłonka (\%) }\end{array}$ & $34.0 \pm 6.8^{\mathrm{aA}}$ & $49.6 \pm 4.0^{\mathrm{bA}}$ & $36.0 \pm 5.5^{\mathrm{aA}}$ & $58.0 \pm 4.3^{\mathrm{cA}}$ \\
\hline \multicolumn{5}{|c|}{ Zone 2 - Strefa 2} \\
\hline $\begin{array}{l}\text { Erythrocytes } \\
\text { Erytrocyty }\end{array}$ & $8.2 \pm 5.6^{\mathrm{aAB}}$ & $54.8 \pm 10.9^{\mathrm{bAB}}$ & $11.2 \pm 6.3^{\mathrm{aAB}}$ & $67.7 \pm 11.6^{\mathrm{bAB}}$ \\
\hline $\begin{array}{l}\text { Individual epithelial cells } \\
\text { Pojedyncze komórki nabłonka }\end{array}$ & $12.9 \pm 6.2$ & $10.0 \pm 3.5$ & $16.7 \pm 7.4$ & $13.9 \pm 7.5$ \\
\hline $\begin{array}{l}\text { Batches of epithelial cells (\%) } \\
\text { „Pakiety” komórek nabłonka (\%) }\end{array}$ & $25.4 \pm 7.3^{\mathrm{aB}}$ & $40.1 \pm 4.9^{\mathrm{bB}}$ & $28.1 \pm 6.4^{\mathrm{aAB}}$ & $49.9 \pm 4.7^{\mathrm{cAB}}$ \\
\hline \multicolumn{5}{|c|}{ Zone 3 - Strefa 3} \\
\hline $\begin{array}{l}\text { Erythrocytes } \\
\text { Erytrocyty }\end{array}$ & $4.6 \pm 4.6^{\mathrm{aB}}$ & $45.2 \pm 14.7^{\mathrm{bC}}$ & $8.0 \pm 5.3^{\mathrm{aC}}$ & $59.8 \pm 13.3^{\mathrm{bC}}$ \\
\hline $\begin{array}{l}\text { Individual epithelial cells } \\
\text { Pojedyncze komórki nabłonka }\end{array}$ & $4.9 \pm 2.4$ & $7.6 \pm 3.7$ & $9.0 \pm 3.8$ & $12.5 \pm 6.0$ \\
\hline $\begin{array}{l}\text { Batches of epithelial cells }(\%) \\
\text { „Pakiety” komórek nabłonka (\%) }\end{array}$ & $12.0 \pm 4.6^{\mathrm{aC}}$ & $31.1 \pm 4.0^{\mathrm{bC}}$ & $18.5 \pm 4.2^{\mathrm{aB}}$ & $42.9 \pm 3.8^{\mathrm{cC}}$ \\
\hline
\end{tabular}

abcd significant differences between the means in rows $(\mathrm{p}<0.05)$.

${ }^{A B C D}$ significant differences between the means in rows $(\mathrm{p}<0.05)$.

${ }^{a b c d}$ różnice istotne między średnimi w wierszach $(\mathrm{p}<0,05)$.

${ }^{\mathrm{ABCD}}$ różnice istotne między średnimi w kolumnach $(\mathrm{p}<0,05)$. 
Herudzińska, M., Kierbić, A., Kmiecik, J., Gehrke, M., Jaśkowski, J. M. (2016). The usage of insemination casing in collecting the cytological material from the cow's uterus in order to reduce the method's invasiveness. Nauka Przyr. Technol., 10, 4, \#55. DOI: http://dx.doi.org/10.17306/J.NPT.2016.4.55

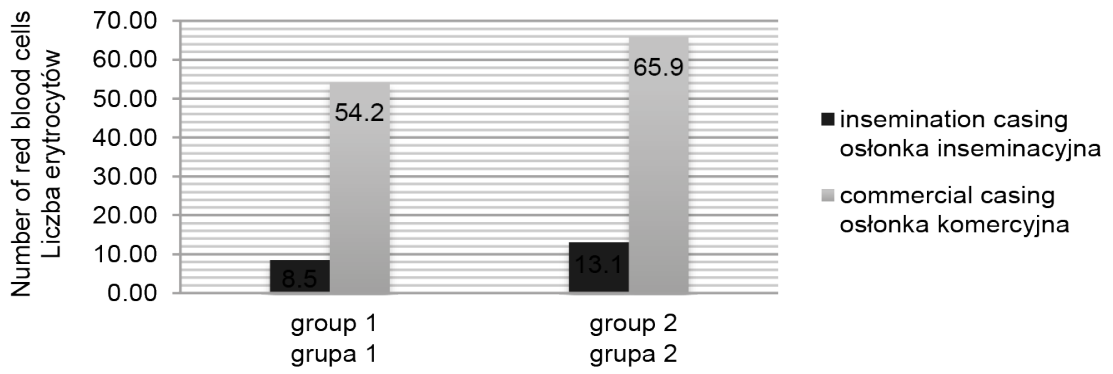

Fig. 7. Average number of red blood cells observed in cytological smear depending on the type of casing used (zone 1, 2 and 3)

Rys. 7. Średnia liczba erytrocytów w rozmazie cytologicznym w zależności od rodzaju zastosowanej osłonki ('średnia wyliczona z wykorzystaniem wyników ze strefy 1, 2 i 3)

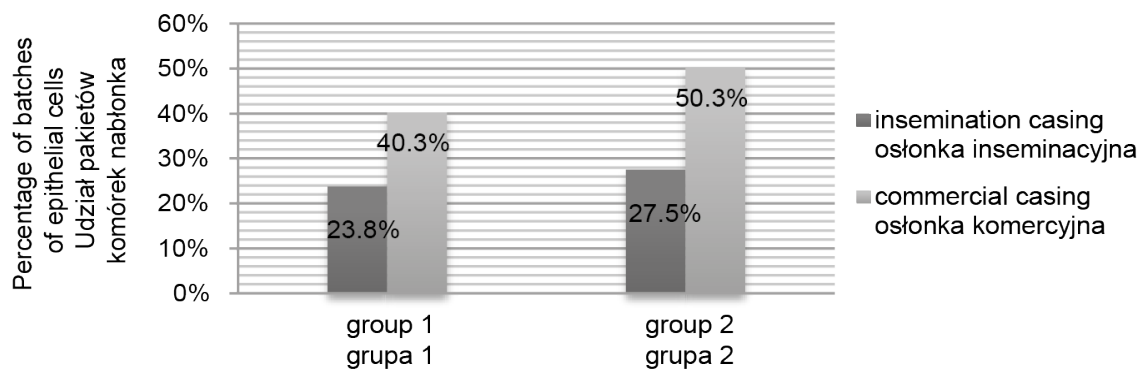

Fig. 8. Percentage of batches of epithelial cells observed in cytological smear depending on the type of casing used (zone 1,2 and 3)

Rys. 8. Udział „pakietów” komórek nabłonka w rozmazie cytologicznym w zależności od rodzaju zastosowanej osłonki (strefa 1, 2 i 3)

in heat, the ones close to it and those outside the estrus period. While evaluating the smears also the percentage of PMNs fraction leucocytes was measured; their presence indicated the state of endometritis (Kasimanickam et al., 2004). The participation of multinucleated neutrophils, described in relation to the sum of individual/desquamated epithelial cells and the general count of leucocytes, was situated in the range between $0 \%$ and $4 \%$. It confirms the assumption stating that no cow showed the endometritis symptoms. According to numerous authors the endometritis is to be suspected in cows with the PMNs percentage exceeding $4-5 \%$ on $45-50$ day after parturition (Barański et al., 2012; Kasimanickam et al., 2004; Madoz et al., 2014).

Madoz et al. (2013) stress that the percentage of PMNs does not change in the estrus period cycle in healthy cows. It is confirmed by the results obtained in the authors' investigations in which small differences between the neutrophils percentage in cows in heat and those outside the estrus period were not statistically significant $(p>0.05)$. The mean percentage of neutrophils was calculated on the basis of two smears carried out for each cow, using both the original cytological set and Cassou gun. The percentage in group 1 was $2.1 \pm 1.2$, whereas in group 2 it was $1.7 \pm 1.4$. 
Herudzińska, M., Kierbić, A., Kmiecik, J., Gehrke, M., Jaśkowski, J. M. (2016). The usage of insemination casing in collecting the cytological material from the cow's uterus in order to reduce the method's invasiveness. Nauka Przyr. Technol., 10, 4, \#55. DOI: http://dx.doi.org/10.17306/J.NPT.2016.4.55

\section{Conclusions}

The suggested method of collecting the material from the uterus of cows, meant for the cytological examination and using the Cassou gun and insemination casing, reduces the risk of micro traumas in the endometrium when compared with the original set. It is especially vital in the case of an examination conducted in the period close to the insemination procedure, when every disturbance of the physiological continuity of the mucosa of the reproductive ducts, especially the uterus, may influence the insemination and carrying the foetus to term.

Absence of changes of the PMNs percentage in the oestrus cycle confirms the universal character of the cytological methods as a diagnostic tool to detect the metritis subclinica. Any increase of the PMNs percentage above the indicated norms, in this case, depending on the postpartum period, may suggest the subclinical endometritis, which presence has to be confirmed by bacteriological examinations.

\section{References}

Ahmadi, M. R., Nazifi, S., Ghaisari, H. R. (2006). Comparison of hormonal changes of estrous cycle with cytology of cervical mucosa and hematological parameters in dairy heifers. Comp. Clin. Pathol., 15, 2, 94-97. DOI: http://dx.doi.org/10.1007/s00580-006-0613-7

Ahmadi, M. R., Tafti, A. K., Nazifi, S., Ghaisari, H. R. (2005). The comparative evaluation of uterine and cervical mucosa cytology with endometrial histopathology in cows. Comp. Clin. Pathol., 14, 2, 90-94. DOI: http://dx.doi.org/ 10.1007/s00580-005-0565-3

Amiridis, G. S., Fthenakis, G. C., Dafopoulos, J., Papanikolaou, T., Mavrogianni, V. S. (2003). Use of cefquinome for prevention and treatment of bovine endometritis. J. Vet. Pharmacol. Ther., 26, 5, 387-390. DOI: http://dx.doi.org/10.1046/j.1365-2885.2003.00490.x

Azawi, O. I. (2008). Postpartum uterine infection in cattle. Anim. Reprod. Sci, 105, 3, 187-208. DOI: http://dx.doi.org/10.1016/j.anireprosci.2008.01.010

Barański, W., Podhalicz-Dziegielewska, M., Zduńczyk, S., Janowski, T. (2012). The diagnosis and prevalence of subclinical endometritis in cows evaluated by different cytologic thresholds. Theriogenology, 78, 1939-1947. DOI: http://dx.doi.org/10.1016/j.theriogenology.2012. 07.018

Dubuc, J., Duffield, T. F., Leslie, K. E., Walton, J. S., LeBlanc, S. J. (2010). Definitions and diagnosis of postpartum endometritis in dairy cows. J. Dairy Sci., 93, 11, 5225-5233. DOI: http://dx.doi.org/10.3168/jds.2010-3428

Gilbert, R. O., Shin, S. T., Guard, C. L., Erb, H. N., Frajblat, M. (2005). Prevalence of endometritis and its effects on reproductive performance of dairy cows. Theriogenology, 64, 9, 18791888. DOI: http://dx.doi.org/10.1016/j.theriogenology.2005.04.022

Kasimanickam, R, Duffield, T. F., Foster, R. A., Gartley, C. J., Leslie, K. E., Walton, J. S. (2005). A comparison of the cytobrush and uterine lavage techniques to evaluate endometrial cytology in clinically normal postpartum dairy cows. Can. Vet. J., 46, 255-259.

Kasimanickam, R., Duffield, T. F., Foster, R. A., Gartley, C. J., Leslie, K. E., Walton, J. S., Johnson, W. H. (2004). Endometrial cytology and ultrasonography for the detection of subclinical endometritis in postpartum dairy cows. Theriogenology, 62, 1, 9-23. DOI: http://dx.doi.org/10.1016/j.theriogenology.2003.03.001

LeBlanc, S. J., Duffield, T. F., Leslie, K. E., Bateman, K. G., Keefe, G. P., Walton, J. S., Johnson, W. H. (2002). Defining and diagnosing postpartum clinical endometritis and its impact on re- 
Herudzińska, M., Kierbić, A., Kmiecik, J., Gehrke, M., Jaśkowski, J. M. (2016). The usage of insemination casing in collecting the cytological material from the cow's uterus in order to reduce the method's invasiveness. Nauka Przyr. Technol., 10, 4, \#55. DOI: http://dx.doi.org/10.17306/J.NPT.2016.4.55

productive performance in dairy cows. J. Dairy Sci., 85, 9, 2223-2236. DOI: http://dx.doi.org/10.3168/jds.S0022-0302(02)74302-6

Madoz, L. V., Giuliodori, M. J., Migliorisi, A. L., Jaureguiberry, M., de la Sota, R. L. (2014). Endometrial cytology, biopsy, and bacteriology for the diagnosis of subclinical endometritis in grazing dairy cows. J. Diary Sci., 97, 1, 195-201. DOI: http://dx.doi.org/10.3168/jds.20136836

Madoz, L. V., Giuliodori, M. J., Jaureguiberry, M., Plöntzke, J., Drillich, M., De la Sota, R. L. (2013). The relationship between endometrial cytology during estrous cycle and cutoff points for the diagnosis of subclinical endometritis in grazing dairy cows. J. Dairy Sci., 2013, 96, 4333-4339. DOI: http://dx.doi.org/10.3168/jds.2012-6269

McDougall, S., Hussein, H., Aberdein, D., Buckle, K., Roche, J., Burke, C. (2011). Relationships between cytology, bacteriology and vaginal discharge scores and reproductive performance in dairy cattle. Theriogenology, 76, 229-240. DOI: http://dx.doi.org/10.1016/j.theriogenology. 2010.12.024

Melcher, Y., Prunner, I., Drillich, M. (2014). Degree of variation and reproducibility of different methods for the diagnosis of subclinical endometritis. Theriogenology, 82, 1, 57-63. DOI: http://dx.doi.org/10.1016/j.theriogenology.2014.03.003

Oral, H., Sozmen, M., Serin, G., Kaya, S. (2009). Comparison of the cytobrush technique, vaginoscopy and transrectal ultrasonography methods for the diagnosis of postpartum endometritis in cows. J. Anim. Vet. Adv., 8, 7, 1252-1255.

Plöntzke, J., Madoz, L. V., De la Sota, R. L., Drillich, M., Heuwieser, W. (2010). Subclinical endometritis and its impact on reproductive performance in grazing dairy cattle in Argentina. Anim. Reprod. Sci., 122, 52-57. DOI: http://dx.doi.org/10.1016/j.anireprosci.2010.07.006

Podhalicz-Dziegielewska, M., Łukaszewicz, G., Janowski, T. (2011). Cytological examination of the cow uterus-description of the method and the preliminary results of its clinical application. Med. Wet., 67, 1, 51-54.

Prieto, M., Barrio, M., Quintela, L. A., Perez-Marin, C. C., Becerra, J. J., Vigo, M. (2012). Validation of a simple method for the interpretation of uterine cytology in cows. Vet. Med. (Praha), 57, 360-363.

Raab, D. (2004). Evaluierung der Cytobrush-Methode zur Diagnostik von subklinischen Endometritiden und Auswirkungen der Entzündung auf die folgende Fruchtbarkeitsleistung von Milchkühen, Dissertation. Berlin, 41-15.

Rodenbusch, S, Ellenberger, C., Hauffe C., Lenz, M., Kiessling, A., Sobiraj, A. (2007). Endometrial biopsy: a useful method to diagnose endometrial changes in subfertile cattle? Reprod. Domest. Anim., 42, 110.

Santos, N. R., Lamb, G. C., Brown, D. R., Gilbert, R. O. (2009). Postpartum endometrial cytology in beef cows. Theriogenology, 71, 739-745. DOI: http://dx.doi.org/10.1016/j.theriogenology. 2008.09.043

Sheldon, I. M., Cronin, J., Goetze, L., Donofrio, G., Schuberth, H. J. (2009). Defining postpartum uterine disease and the mechanisms of infection and immunity in the female reproductive tract in cattle. Biol. Reprod., 81, 6, 1025-1032. DOI: http://dx.doi.org/10.1095/biolreprod.109. 077370

Sheldon, I. M., Lewis, G. S., LeBlanc, S., Gilbert, R. O. (2006). Defining postpartum uterine disease in cattle. Theriogenology, 65, 8, 1516-1530. DOI: http://dx.doi.org/10.1016/j.therio genology.2005.08.021

Walter, J., Neuberg, K. P., Failing, K., Wehrend, A. (2012). Cytological diagnosis of endometritis in the mare: investigations of sampling techniques and relation to bacteriological results. Anim. Reprod. Sci., 132, 3, 178-186. DOI: http://dx.doi.org/10.1016/j.anireprosci.2012. 05.012 
Herudzińska, M., Kierbić, A., Kmiecik, J., Gehrke, M., Jaśkowski, J. M. (2016). The usage of insemination casing in collecting the cytological material from the cow's uterus in order to reduce the method's invasiveness. Nauka Przyr. Technol., 10, 4, \#55. DOI: http://dx.doi.org/10.17306/J.NPT.2016.4.55

\title{
ZASTOSOWANIE OSŁONKI INSEMINACYJNEJ PRZY POBIERANIU MATERIAŁU CYTOLOGICZNEGO Z MACICY KRÓW W CELU ZMNIEJSZENIA INWAZYJNOŚCI METODY
}

\begin{abstract}
Streszczenie
Wstęp. Schorzenia macicy są jednym z głównych czynników ograniczających płodność krów. Spośród różnych form poporodowego zapalenia macicy u tego gatunku podkliniczne zapalenie (metritis subclinica) stanowi szczególny problem ze względu na trudności diagnostyczne. W celu poszerzenia skuteczności w rozpoznawaniu chorób macicy w praktyce stosuje się m.in. cytologię. Pobieranie materiału do badań cytologicznych jest jednak metodą inwazyjną - stwarza ryzyko mikrourazów, szczególnie w trakcie przemieszczania szczoteczki przez kanał szyjki macicznej. Celem naszej pracy było porównanie stopnia inwazyjności metody, w której wykorzystywane powszechnie osłonki szczoteczek cytologicznych („ostro” zakończone) zastąpiono osłonką inseminacyjną (zaokrągloną na końcu).

Material i metody. Materiał do badania cytologicznego pobierano każdą z metod od 60 różnych krów, u których nie stwierdzono cech zapalenia macicy. Materiał cytologiczny przenoszono na szkiełka podstawowe metodą „rolowania”. Preparaty utrwalono preparatem Cytofix (firmy SAN$\mathrm{KO}$ ), wybarwiono, korzystając z zestawu odczynników RapiChem (firma AQUA-MED) i poddano ocenie cytologicznej. Określono średnią liczbę erytrocytów i komórek nabłonka w 50 polach widzenia (pow. 100x) oraz odsetek złuszczonych fragmentów nabłonka (powyżej 10 komórek). Ocenę wykonano w trzech strefach rozmazu odpowiadających wierzchołkowi szczoteczki (strefa I), jej środkowej części (strefa II) oraz podstawie (strefa III).

Wyniki i wnioski. Porównanie wyników badania cytologicznego uzyskanego obiema metodami wskazało, że liczba erytrocytów i odsetek fragmentów złuszczonego nabłonka oceniany w strefie pierwszej odzwierciedla urazowość zabiegu. Zastosowanie osłonki inseminacyjnej do zabiegu nie eliminuje uszkodzeń nabłonka w trakcie przechodzenia przez kanał szyjki macicy, lecz redukuje inwazyjność metody mierzoną ilością złuszczonych fragmentów nabłonka. Niska liczba erytrocytów w rozmazach pobranych $\mathrm{z}$ wykorzystaniem osłonki inseminacyjnej wskazuje, że ten typ osłonki skutecznie zabezpiecza przed powstawaniem głębokich urazów.
\end{abstract}

Słowa kluczowe: cytologia, szczoteczka cytologiczna, osłonka inseminacyjna, pistolet Cassou, SEND, metritis

Corresponding address - Adres do korespondencji:

Magdalena Herudzińska, Stugocin 34,62-406 Lądek, Poland, e-mail: magdalenaherudzinska6@ gmail.com

Accepted for publication - Zaakceptowano do opublikowania:

15.12.2016

For citation - Do cytowania:

Herudzińska, M., Kierbić, A., Kmiecik, J., Gehrke, M., Jaśkowski, J. M. (2016). The usage of insemination casing in collecting the cytological material from the cow's uterus in order to reduce the method's invasiveness. Nauka Przyr. Technol., 10, 4, \#55. DOI: http://dx.doi.org/10. 17306/J.NPT.2016.4.55 